\title{
Plant physiological impacts and flavonoid metabolic responses to uptake $\mathrm{TiO}_{2}$ nanoparticles
}

\author{
Kanokporn Sompornpailin", Wilailack Chayaprasert
}

College of Nanotechnology, King Mongkut's Institute of Technology Ladkrabang, Bangkok, 10520 Thailand

\author{
*Correspondence author: kanokporn.so@kmitl.ac.th
}

\begin{abstract}
The presence of Titanium dioxide nanoparticles $\left(\mathrm{TiO}_{2} \mathrm{NPs}\right)$ contamination in the environment is of concern because of their oxidative effect on organisms. Transgenic tobaccos that overexpressed PAP1, a MYB75 gene, were used to investigate the response of plants to the presence of $\mathrm{TiO}_{2} \mathrm{NPs}$ and the results were compared to those for wild type (WT) plants. The experiment was performed under tissue culture conditions with daylight fluorescence. The physiological responses of the plants under moderately low concentrations of $\mathrm{TiO}_{2}$ NPs (20-40 $\left.\mathrm{mg} \mathrm{L}^{-1}\right)$ were analyzed in relation to metabolic responses and the results were compared to those of plants under zero $\mathrm{TiO}_{2}$ conditions. Under conditions of $20 \mathrm{mg} \mathrm{L}^{-1} \mathrm{TiO}_{2}, \mathrm{WT}$ and PAP1 plants showed better physiology than plants under other conditions. These plants had higher chlorophyll and carotenoid levels, and better membrane stability than plants under non $\mathrm{TiO}_{2}$ conditions. The WT plants grown in medium at $40 \mathrm{mg} \mathrm{L}^{-1} \mathrm{TiO}_{2}$ showed deteriorated physiology, while PAP1 plants grown under the same condition were shown various changes in physiology depending on the line. Moreover, the content of total soluble sugar (TSS) and flavonoids in the extracts of plant were increased in response to the concentrations of $\mathrm{TiO}_{2}$. However, all PAP1 transgenics had flavone and flavonol contents that were approximately 2-3 times the levels found in WT plants, while TSS and anthocyanin subgroup levels were not different among the WT and transgenic plants. Excessive nanoparticles can induce oxidative damage in cells, and it appears that PAP1 transgenics can alleviate such damage by enhancing flavonoid accumulation.
\end{abstract}

Keywords: flavone, flavonol, MYB75, membrane injury, metal nanoparticles, sugar, titanium.

Abbreviations: A_Absorbance; EC_electrical conductivity; FW_fresh weight; MDA_malondialdehyde; MS_Murashige and Skoog medium; PAP1_PRODUCTION OF ANTHOCYANIN PIGMENT 1; ROSs_reactive oxygen species; TBARS_thiobarbituric acid-reactivesubstances assay; $\mathrm{TiO}_{2}$ NPs_titanium dioxide nanoparticles; TSS_total soluble sugar: WT_wild type.

\section{Introduction}

The functions and applications of nanoparticles have become important research topics. Nowadays, $\mathrm{TiO}_{2} \mathrm{NPs}$ has become key parts of industrial production for food, drugs, cosmetics, electronic devices, textiles, paints and plastics. Annual industrial demand has reached several million tons of $\mathrm{TiO}_{2}$ worldwide (Gázquez et al., 2014). However, $\mathrm{TiO}_{2} \mathrm{NPs}$ contamination in the environment has dramatically increased, especially in the agricultural soils. Environmental contamination of $\mathrm{TiO}_{2}$ can have both advantageous and disadvantageous effects on organisms. Plant root systems directly uptake inorganic elements, including titanium, from the soils and use these elements in the biosynthesis of various organic substances. The organic substances synthesized by plants serve as nutrient supplies for animals and humans at various places in the food web. Therefore, contamination of the environment with $\mathrm{TiO}_{2} \mathrm{NPs}$ is of increasing concern, particularly in relation to human health (Stander and Theodore, 2011).

Titanium dioxide is a common compound that possesses photocatalytic properties under UV irradiation (Schneider et al., 2014). Titanium, a transition element, is considered to be a potentially beneficial element for the physiological functions of plants (Pilon-Smits et al., 2009). $\mathrm{TiO}_{2} \mathrm{NPs}$ have been reported to promote growth and development of plants, and for many examples, they may increase shoot and root lengths. Furthermore, $\mathrm{TiO}_{2} \mathrm{NPs}$ enhance chlorophyll and protein levels in Arabidopsis and various kinds of higher plants (Gao et al., 2008; Ze et al., 2011 Raliya et al., 2014). On the other hand, genotoxicity and phytotoxicity effects of NPs on growth rate and cellular senescence of plants have also been discussed (Hong et al., 2005a; Ruffini et al., 2010; Raliya et al., 2014). The concentration of $\mathrm{TiO}_{2}$ NPs has significant influence on the 
physiological responses of various plant species. However, the response mechanisms of plants against $\mathrm{TiO}_{2} \mathrm{NPs}$ are complex and remain incompletely understood.

The nanoparticles uptaken by plants deduce modifications of plant growth and development (Da Costa and Sharma, 2016; Wang et al., 2015; Marslin et al., 2017). Most studies reported that high concentrations of NPs were toxic to the plants (Miralles et al., 2012). Plant alters their cellular levels of several metabolites in response to the types and concentration of nanoparticles in their environment (Chayaprasert and Sompornpailin, 2017). Soluble sugars are the basic energy resources that are commonly accumulated in plant tissues or organs. The level of soluble sugar rapidly changes according to the environmental conditions (Rosa et al., 2009). These soluble sugars can act as messengers in the signal transduction processes and regulate the expression of genes involved in several pathways (Rolland et al., 2006). Many researchers have reported that sugar is involved in both positively and negatively regulating gene expressions of plant secondary metabolites at the transcriptional level (Rosa et al., 2009). For example, sucrose can induce the expression of flavonoidinvolved gene and; thus, enhance flavonoid accumulation in plant cells (Solfanelli et al., 2006; Jeong et al., 2010).

Flavonoids are a group of important organic compounds that can be synthesized in most land plants. Plants synthesize different subgroups of flavonoids, according to developmental stages and environmental conditions. Flavonoids have broad biological activities in both plants and humans because various chemical structures are present. These compounds are classified into subgroups depending on the oxidative stage of the $C$ ring in their structure ( $\varnothing$ yvind and Kenneth, 2006). An important activity of flavonoids is the mitigation of oxidative effects by reducing levels of reactive oxygen species (ROSs) on the stressed cells. This occurs because of the antioxidant properties of flavonoids. Our previous research showed that transgenic overexpressing PRODUCTION OF ANTHOCYANIN PIGMENT 1 (PAP1), a regulatory gene, strongly promoted synthesis of flavonoids in response to light stresses, and also increase cell protection (Sompornpailin and Kanthang, 2015). This was similar to a result for Arabidopsis (Kaveh et al., 2013). Metal oxide nanoparticles have the potential to induce oxidative stress in plants and; thus, affect gene expression and enzymatic activity levels (Ruffini et al., 2010; Kaveh et al., 2013). Therefore, these transgenic plants are used to study the responses to $\mathrm{TiO}_{2} \mathrm{NPs}$ and the results are compared to those for WT plant. The research aim is to better understand plant response to $\mathrm{TiO}_{2} \mathrm{NPs}$ and functions of flavonoids in plant cells. In this study, $\mathrm{TiO}_{2}$ NPs were used as components in plant tissue culture medium to study their influence on the level of light harvesting pigments and membrane integrity of the plants used. The contents of sugar and flavonoid subgroups in WT and transgenic tissues of the $\mathrm{TiO}_{2} \mathrm{NPs}$ treated plants were measured. These contents are considered to be physiological adaptations of the plants to the specific concentration of $\mathrm{TiO}_{2}$ NPs and are related to the stabilities of light harvesting pigments and the integrity of plant cells.

\section{Results and Discussion}

$\mathrm{TiO}_{2} \mathrm{NPs}$ in the medium can be trans-located into the plant system and affect cells and organelles. Plants adapt the biosynthetic rate of metabolic networks, according to the concentration of nanoparticles. The relationships of various metabolite accumulations in the tissue and level of photosynthetic pigments are presented. The cell membrane integrity of plant tissue grown under medium containing different concentration of $\mathrm{TiO}_{2} \mathrm{NPs}$ was assessed by analyzing the percentage of electrolyte leakage and malondialdehyde (MDA) level. MDA is a byproduct of the oxidative reaction of cell membrane damage and its level is indication of the physiological status of the plant.

\section{Effects of $\mathrm{TiO}_{2} \mathrm{NPs}$ on photosynthetic pigment contents}

The contents of photosynthetic pigments, especially chlorophylls, are known as major indexes for evaluating quality of plant physiology. The different concentrations $\left(0-40 \mathrm{mg} \mathrm{L}^{-1}\right)$ of $\mathrm{TiO}_{2} \mathrm{NPs}$ in tissue culture medium produced diverse physiological effects on WT and transgenic plants. Although the photosynthetic pigment levels of plant tissue are variable depending on transgenic lines, under the conditions of this experiment, $20 \mathrm{mg} \mathrm{L}^{-1} \mathrm{TiO}_{2} \mathrm{NPs}$ added to the medium slightly enhanced the levels of the main photosynthetic pigment (chlorophyll a) in WT and in most transgenic plants by $2-10 \%$. Furthermore, this concentration of $\mathrm{TiO}_{2} \mathrm{NPs}$ in the medium was associated with an increase in the levels of minor pigments, chlorophyll b (by 15-30\%) and carotenoids (by 20$40 \%$ ) in WT and transgenic plants in comparison to the same plants grown in normal medium (Table 1 ).

In contrast to the results seen for plants grown in a medium with $20 \mathrm{mg} \mathrm{L}^{-1} \mathrm{TiO}_{2} \mathrm{NP}$, WT plants grown in $40 \mathrm{mg} \mathrm{L}^{-1} \mathrm{TiO}_{2} \mathrm{NPs}$ medium showed reduced levels of chlorophyll $a$, chlorophyll $b$ and carotenoids by $26.6 \%, 17.6 \%$ and $2.9 \%$ respectively, when compared to their growth in the normal MS medium. Under conditions of $40 \mathrm{mg} \mathrm{L}^{-1} \mathrm{TiO}_{2} \mathrm{NPs}$ medium, the chlorophyll a of these transgenic was at a similar level to the same transgenics grown under normal medium, while the chlorophyll $b$ and carotenoid levels in most transgenics were slightly higher than those in plant under normal conditions. This finding implied that $40 \mathrm{mg} \mathrm{L}^{-1} \mathrm{TiO}_{2}$ medium may be less (or non-toxic) to transgenic plants containing PAP1 than it is to WT plants.

Titanium and iron are metallic elements that have similar atomic size and electronegativity. Therefore, they may be able to interchange in organic structures and catalytic functions. For example, researchers reported that the titanium ion has the potential to take the place of the magnesium ion in chlorophyll pigments (Dujardin et al., 1975). Therefore, in this experiment, adding $20 \mathrm{mg} \mathrm{L}^{-1} \mathrm{TiO}_{2}$ to the medium slightly enhanced the percentage of chlorophyll a and highly increased the percentages of chlorophyll $b$ and carotenoids. On the other hand, higher levels of titanium antagonize systems centered on iron (Lyu et al., 2017) or other elements.

\section{Effects of $\mathrm{TiO}_{2} \mathrm{NPs}$ on cell membrane integrity}

$\mathrm{TiO}_{2}$ NPs have a potential to induce oxidative damages on lipid membrane and produces MDA as a byproduct. The results of MDA level tests of the plant are present in Fig 1A. Damaged membranes lose the ability to control the release of ions, and therefore enhanced electrolyte leakage from cells occurs when membranes are damaged. The electrolyte leakage from plant 
cells under various conditions is presented as a percentage of cell membrane injury in Fig $1 \mathrm{~B}$.

At the $20 \mathrm{mg} \mathrm{L}^{-1} \mathrm{TiO}_{2}$ NPs condition, WT and transgenic plants have a content of MDA, approximately $20-50 \%$ lower than those plants under the MS condition. Similarly, in terms of the percentage of cell membrane injury, under this condition, both WT and transgenics showed a $10-35 \%$ reduction of cell membrane injury compared to the MS condition. The MDA levels of plants grown in $40 \mathrm{mg} \mathrm{L}^{-1} \mathrm{TiO}_{2} \mathrm{NPs}$ are the same or only slightly lower (depending on plant line) compared to those of plants grown in the non $\mathrm{TiO}_{2} \mathrm{NPs}$ condition. Medium containing $40 \mathrm{mg} . \mathrm{L}^{-1} \mathrm{TiO}_{2} \mathrm{NPs}$ slightly induces and increases the percentage of cell membrane injury in tissues of WT and some transgenic lines ( $\mathrm{T} 1$ and $\mathrm{T} 2$ ), while the same conditions did not have much effect on those plants in T3 and T4 transgenics. T5 Transgenic, grown in $40 \mathrm{mg}$. $\mathrm{L}^{-1} \mathrm{TiO}_{2} \mathrm{NPs}$, showed higher MDA levels than the normal condition. However, in the same $40 \mathrm{mg} \cdot \mathrm{L}^{-1} \mathrm{TiO}_{2} \mathrm{NPs}$ condition, this transgenic line displayed a percentage of cell membrane injury that was similar to the non $\mathrm{TiO}_{2}$ NPs condition.

From the results of physiological parameters, photosynthetic pigment contents, MDA levels and the percentage of cell membrane injury, both WT and transgenic tobacco plants grown in the $20 \mathrm{mg} \mathrm{L}^{-1} \mathrm{TiO}_{2} \mathrm{NPs}$ medium presented better plant physiology than plants grown in non $\mathrm{TiO}_{2}$ containing medium. The conclusion that $\mathrm{TiO}_{2}$ NPs can promote plant growth is similar to that found for spinach and mung beans (Hong et al., 2005b; Zheng et al., 2005; Raliya et al., 2014). $\mathrm{TiO}_{2}$ NPs have been reported to enhance energy utilization and improve efficiency of the photosynthetic system (Su et al., 2009). Titanium is the second most abundant transition metal after iron (Fe), and this element has synergistic functions with Fe and enhances Fe uptake in plants (Lyu et al., 2017). Therefore, it is considered as a micronutrient that has beneficial effects for plant growth and development.

The severity effect of $\mathrm{TiO}_{2} \mathrm{NPs}$ depends on their concentration and the adaptation of each plant variety. Media containing moderately high concentrations of $\mathrm{TiO}_{2} \mathrm{NPs}\left(40 \mathrm{mg} \mathrm{L}^{-1}\right)$ affect WT and transgenic plants in different ways. $\mathrm{TiO}_{2} \mathrm{NPs}$ at a concentration of $40 \mathrm{mg} \mathrm{L}^{-1}$ in medium seem to induce deleterious effects on WT plants because negative physiological results are presented. The percentage of cell membrane injury is increased, and photosynthetic pigment contents in WT are decreased. This is in agreement with previous reports that found that NPs stimulated plant growth in low concentrations, but inhibited plant growth at high concentrations (Song et al., 2012).

The fact that higher levels of photosynthetic pigments have been observed for plants grown under the $\mathrm{TiO}_{2} \mathrm{NPs}$ condition seems to indicate that plants have been grown under ideal conditions. However, high level of photosynthetic pigments may lead to accumulation and; thus, high levels of ROS, which are byproducts of oxygenic photosynthesis in plant systems. Mohammadi et al. (2014) also found that chickpea grown under $\mathrm{TiO}_{2} \mathrm{NPs}$ and stress conditions showed increased levels of both ROS and chlorophyll. Furthermore, our results are also similar to those found for phytotoxicity under conditions of high $\mathrm{TiO}_{2}$ concentration in maize and rice (Yang et al., 2015). In addition, $\mathrm{TiO}_{2}$ NPs are well-known as photo-catalysts under ultraviolet radiation and visible light. Thus, they have the potential to induce oxidative stress in plant cells. Nanoparticles oxidize water, which is a major component of cells. This reaction generates hydroxyl radicals $\left(\mathrm{OH}^{-}\right)$and superoxide $\left(\mathrm{O}^{2-}\right.$ ), which is a potent ROSs. Normally, the cells produce these ROSs at an appropriate level for their cellular metabolism. For this reason, $\mathrm{TiO}_{2} \mathrm{NPs}$ at concentration of $40 \mathrm{mg}$. $\mathrm{L}^{-1}$ in medium might induce the generating ROSs in WT plant at high levels. Higher levels of ROS may severely damage cell membranes, and thus the percentage of cell membrane injury is increased, and the contents of photosynthetic pigments decreased.

\section{Effects of $\mathrm{TiO}_{2} \mathrm{NPs}$ on metabolic responses}

The level of TSS was increased in both WT and transgenic plants, grown in medium containing 20 and $40 \mathrm{mg} \mathrm{L}^{-1} \mathrm{TiO}_{2} \mathrm{NPs}$ (Fig 2). The level of TSS in WT plants grown under 20 and 40 $\mathrm{mg} \mathrm{L}^{-1} \mathrm{TiO}_{2} \mathrm{NPs}$ media was increased by 1.3 and 1.5 times, respectively, compared to that for WT plants under non $\mathrm{TiO}_{2}$ conditions. The level of TSS in transgenic plants grown in medium containing 20 and $40 \mathrm{mg} \mathrm{L}^{-1} \mathrm{TiO}_{2}$ NPs MS media was increased in the range of 1.1-1.3 and 1.1-1.5 times respectively, compared to the levels in plants grown in non $\mathrm{TiO}_{2}$ NPs medium. The WT plants showed a higher rate of TSS accumulation in tissues than was observed for most transgenic lines. However, the basal levels of TSS in the tissue of the transgenic lines, with the exception of T2 line, were higher than basal levels in the WT plants.

The levels of flavonoids in WT and transgenic plants were enhanced depending on the concentration of $\mathrm{TiO}_{2} \mathrm{NPs}$ in the medium (Table 2). The flavone content of tobacco plants grown in $20 \mathrm{mg} \mathrm{L}^{-1} \mathrm{TiO}_{2}$ NPs medium was about 1.1 times that of WT plants and about 1.1-1.3 times the value found for transgenic plants, when compared to their growth in the non $\mathrm{TiO}_{2}$ NPs medium. The flavonol contents of WT and transgenic tobacco plants grown in $20 \mathrm{mg} \mathrm{L}^{-1} \mathrm{TiO}_{2} \mathrm{NPs}$ medium showed about 1.1 times and 1.1-1.8 times greater values, respectively. At this concentration of $\mathrm{TiO}_{2}$ medium, the levels of an anthocyanin subgroup in WT and transgenic plants were about 1.2 times and 1.1-1.4 times greater than levels in the same plants under normal conditions. The highest content of the flavonoid subgroups was found in all plants grown in $40 \mathrm{mg} \mathrm{L}^{-1}$ $\mathrm{TiO}_{2}$ NPS MS condition. Under these conditions, WT plants contained flavone, flavonol and anthocyanin about 1.3, 2.3 and 1.4 times the levels of WT plants grown in non $\mathrm{TiO}_{2}$ medium. Under the same conditions, transgenic plants contained flavone, flavonol and anthocyanin contents at levels that were 1.1-1.5, 1.1-2.2 and 1.2-1.7 times higher than levels for plants grown under normal MS condition. These transgenic plants contained flavone and flavonol subgroups at higher levels than found for WT plant (2-3 times and 1.4-1.7 times, respectively). The content of the anthocyanin subgroup for WT and most transgenics did not differ among the plants at the same condition. T3 transgenic had the highest content of all flavonoid subgroups. In a similar way, this transgenic line had the highest accumulation of flavonoid subgroup in response to $\mathrm{TiO}_{2}$ NPs levels.

Depending on their stage of development and environmental conditions, plants modulate their metabolisms and synthesize 
Table 1. Pigment contents ( $\mu \mathrm{g} \mathrm{g}^{-1} \mathrm{FW}$ ) in leaf tissue of wild type (WT) and PAP1 transgenic line (T1 to T5) grown under tissue culture condition in MS medium with 0,20 and $40 \mathrm{mg} \mathrm{L}^{-1} \mathrm{TiO}_{2} \mathrm{NPs}$.

\begin{tabular}{|c|c|c|c|c|c|c|c|c|c|}
\hline \multirow[t]{2}{*}{ Plant line } & \multicolumn{3}{|c|}{ Chlorophyll a } & \multicolumn{3}{|c|}{ Chlorophyll b } & \multicolumn{3}{|c|}{ Carotenoid } \\
\hline & MS & $20 \mathrm{TiO}_{2}$ & $40 \mathrm{TiO}_{2}$ & MS & $20 \mathrm{TiO}_{2}$ & $40 \mathrm{TiO}_{2}$ & MS & $20 \mathrm{TiO}_{2}$ & $40 \mathrm{TiO}_{2}$ \\
\hline WT & $28.2 \pm 0.4^{b}$ & $29.6 \pm 0.3^{\mathrm{a}}$ & $20.7 \pm 0.3^{c}$ & $9.1 \pm 0.5^{\mathrm{e}}$ & $10.4 \pm 0.7^{d}$ & $7.4 \pm 0.3^{f}$ & $7.3 \pm 0.6^{h}$ & $9,0 \pm 0.5^{g}$ & $7.1 \pm 0.1^{h}$ \\
\hline T1 & $31.3 \pm 0.5^{a}$ & $31.8 \pm 0.2^{\mathrm{a}}$ & $31.3 \pm 0.3^{\mathrm{a}}$ & $9.6 \pm 0.1^{f}$ & $11.9 \pm 0.3^{d}$ & $11.1 \pm 0.4^{\mathrm{e}}$ & $8.6 \pm 0.1^{h}$ & $10.2 \pm 0.3^{g}$ & $8.6 \pm 0.0^{h}$ \\
\hline $\mathrm{T} 2$ & $33.5 \pm 0.1^{c}$ & $34.7 \pm 0.4^{a}$ & $34.2 \pm 0.1^{b}$ & $10.5 \pm 0.1^{\mathrm{e}}$ & $12.1 \pm 0.3^{d}$ & $11.1 \pm 0.4^{\mathrm{e}}$ & $8.7 \pm 0.6^{h}$ & $10.0 \pm 0.2^{\mathrm{g}}$ & $10.0 \pm 0.1^{h}$ \\
\hline T3 & $25.3 \pm 0.2^{b}$ & $28.4 \pm 0.4^{a}$ & $25.5 \pm 0.6^{b}$ & $11.0 \pm 0.2^{f}$ & $14.2 \pm 0.6^{d}$ & $11.9 \pm 0.3^{\mathrm{e}}$ & $5.2 \pm 0.2^{i}$ & $7.8 \pm 0.2^{\mathrm{g}}$ & $5.7 \pm 0.1^{h}$ \\
\hline T4 & $25.7 \pm 0.4^{b}$ & $27.0 \pm 0.1^{\mathrm{a}}$ & $26.6 \pm 0.0^{\mathrm{a}}$ & $9.2 \pm 0.2^{\mathrm{e}}$ & $9.5 \pm 0.4^{\mathrm{e}}$ & $10.9 \pm 0.3^{d}$ & $7.7 \pm 0.1^{i}$ & $9.2 \pm 0.1^{\mathrm{g}}$ & $8.3 \pm 0.1^{\mathrm{h}}$ \\
\hline T5 & $27.0 \pm 0.1^{\mathrm{c}}$ & $30.2 \pm 0.1^{\mathrm{a}}$ & $28.3 \pm 0.2^{b}$ & $9.5 \pm 0.1^{\mathrm{e}}$ & $11.1 \pm 0.4^{d}$ & $8.5 \pm 0.7^{e}$ & $7.8 \pm 0.1^{\mathrm{h}}$ & $9.4 \pm 0.3^{\mathrm{g}}$ & $8.0 \pm 0.2^{\mathrm{h}}$ \\
\hline
\end{tabular}

Different letters in each row of the same material represent a significant difference at $\mathrm{p} \leq 0.05$
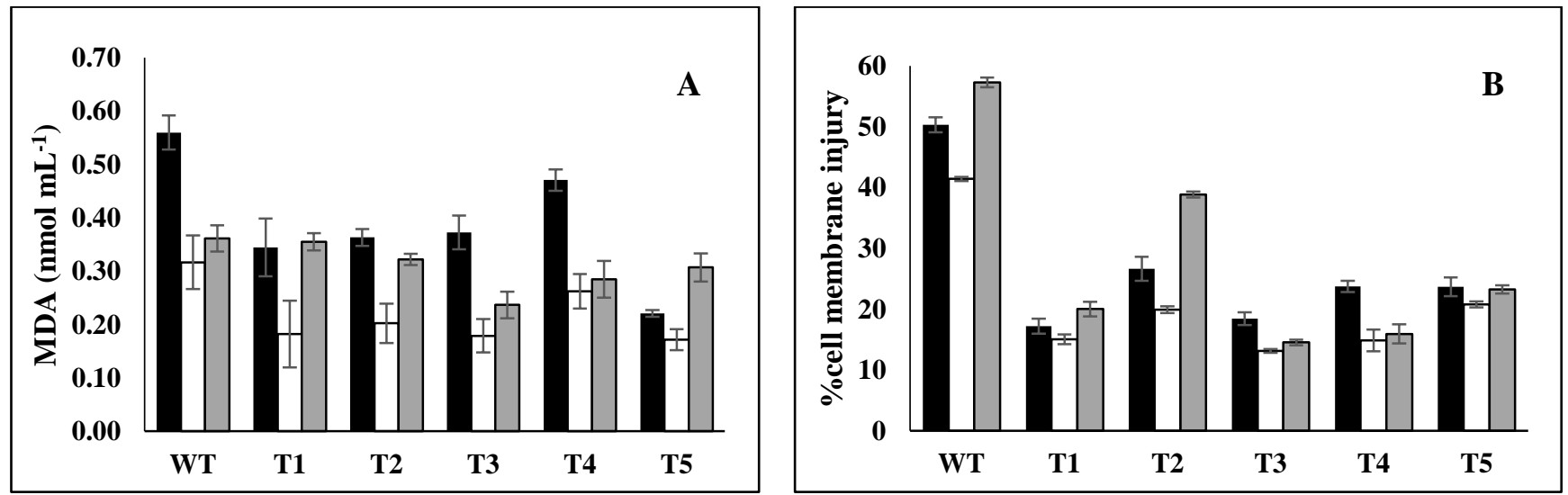

Fig 1. Effects of $\mathrm{TiO}_{2}$ NPs on cell membrane integrity: A Malondialdehyde (MDA) content ( $\mathrm{nmol} \mathrm{mL}$ ), B Percentage of cell membrane injury in wide type (WT) and PAP1 transgenic plant lines (T1 to T5) grown in MS with $\square, \square 20, \square 40 \mathrm{mg}^{-1} \mathrm{~L}^{-1} \mathrm{TiO}_{2} \mathrm{NPs}$ added.

Table 2. Flavonoid content ( $\mathrm{g}^{-1} \mathrm{FW}$ ) in wild type (WT) and PAP1 transgenic plants (T1 to T5) grown on MS supplemented with 0,20 and $40 \mathrm{mg} \mathrm{L}^{-1} \mathrm{TiO}_{2}$ NPs.

\begin{tabular}{|c|c|c|c|c|c|c|c|c|c|}
\hline Plant line & \multicolumn{3}{|l|}{ Flavone } & \multicolumn{3}{|l|}{ Flavonol } & \multicolumn{3}{|l|}{ Anthocyanin } \\
\hline WT & $6.08 \pm 0.08^{c}$ & $6.31 \pm 0.07^{b}$ & $7.58 \pm 0.17^{\mathrm{a}}$ & $0.75 \pm 0.01^{f}$ & $0.83 \pm 0.02^{\mathrm{e}}$ & $1.74 \pm 0.04^{d}$ & $0.044 \pm 0.003^{i}$ & $0.054 \pm 0.002^{h}$ & $0.062 \pm 0.001^{\mathrm{g}}$ \\
\hline T1 & $11.06 \pm 0.13^{c}$ & $12.5 \pm 0.35^{b}$ & $15.7 \pm 0.27^{\mathrm{a}}$ & $1.31 \pm 0.04^{f}$ & $2.25 \pm 0.12^{\mathrm{e}}$ & $2.86 \pm 0.04^{d}$ & $0.046 \pm 0.002^{i}$ & $0.054 \pm 0.005^{h}$ & $0.059 \pm 0.003^{g}$ \\
\hline $\mathrm{T} 2$ & $12.37 \pm 0.08^{c}$ & $14.43 \pm 0.31^{b}$ & $16.28 \pm 0.14^{\mathrm{a}}$ & $1.14 \pm 0.00^{f}$ & $1.72 \pm 0.02^{\mathrm{e}}$ & $2.22 \pm 0.15^{d}$ & $0.049 \pm 0.002^{i}$ & $0.055 \pm 0.001^{\mathrm{h}}$ & $0.065 \pm 0.005^{\mathrm{g}}$ \\
\hline T3 & $14.67 \pm 0.12^{c}$ & $19.31 \pm 0.30^{b}$ & $21.16 \pm 0.19^{\mathrm{a}}$ & $2.19 \pm 0.14^{f}$ & $2.70 \pm 0.08^{\mathrm{e}}$ & $2.96 \pm 0.02^{d}$ & $0.057 \pm 0.004^{i}$ & $0.065 \pm 0.001^{\mathrm{h}}$ & $0.070 \pm 0.004^{\mathrm{g}}$ \\
\hline T4 & $13.47 \pm 0.22^{c}$ & $18.03 \pm 0.01^{b}$ & $19.63 \pm 0.25^{\mathrm{a}}$ & $1.89 \pm 0.01^{f}$ & $1.97 \pm 0.00^{\mathrm{e}}$ & $2.46 \pm 0.13^{d}$ & $0.047 \pm 0.001^{i}$ & $0.053 \pm 0.004^{h}$ & $0.059 \pm 0.003^{8}$ \\
\hline T5 & $11.74 \pm 0.03^{c}$ & $12.27 \pm 0.24^{\mathrm{b}}$ & $15.57 \pm 0.16^{\mathrm{a}}$ & $1.41 \pm 0.01^{f}$ & $1.56 \pm 0.03^{\mathrm{e}}$ & $1.61 \pm 0.00^{d}$ & $0.045 \pm 0.002^{i}$ & $0.050 \pm 0.001^{h}$ & $0.055 \pm 0.001^{8}$ \\
\hline
\end{tabular}

Different letters in each row of the same materials represent significant differences at $p \leq 0.05$

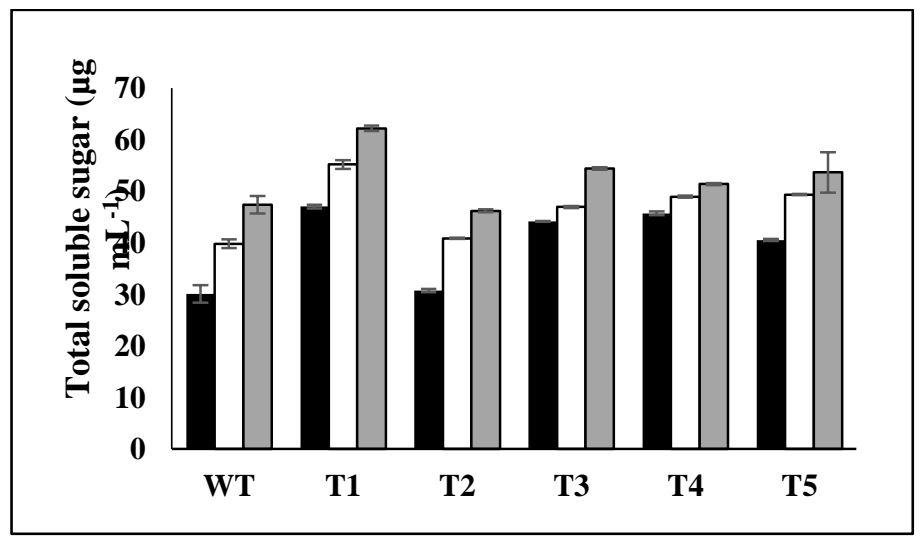

Fig 2. Total soluble sugar ( $\mu \mathrm{g} \mathrm{mL}^{-1}$ ) in leaf tissue of wild type (WT) and PAP1 transgenic plant line (T1 to T5) grown in MS with $\mathbf{\square} 0, \square 20$, $\square 40 \mathrm{mg} \mathrm{L}^{-1} \mathrm{TiO}_{2}$ NPs added. Data shows mean values of three replicates \pm SD. 
specific metabolites for cellular defense. In this experiment, flavonoid and sugar compounds in plant tissue were studied, and the levels of both groups of metabolites were influenced by the presence of $\mathrm{TiO}_{2} \mathrm{NPs}$, with the effects being particularly noticeable in transgenic plants. In general, the sugar content found within a plant was in concordance with total flavonoid content within the same plant. However, the levels of these metabolites were not directly related to the plant physiological status. Under the $20 \mathrm{mg} \mathrm{L}^{-1} \mathrm{TiO}_{2} \mathrm{NPs}$ condition, photosynthetic pigments in plant tissue were increased. This evidence implied that photosynthetic rate of the plant had been enhanced. It had been noted that the photosynthetic rate and level of accumulated sugar are coordinately regulated by a metabolic network (Rolland et al., 2006). The $40 \mathrm{mg} \mathrm{L}^{-1} \mathrm{TiO}_{2}$ NPs condition slightly induced stress into the cellular physiology of the WT plants as mentioned above. Under this stress condition, the level of total soluble sugar in the WT plant tissues was not related to the content of photosynthetic pigments because the plants attempted to adjust their metabolites to handle the stress.

Soluble sugars are basal metabolites that are quickly synthesized in response to oxidative stress. The level of total soluble sugar in plant tissues found in plants grown in the 40 $\mathrm{mg} \mathrm{L}^{-1} \mathrm{TiO}_{2} \mathrm{NPs}$ condition was very high. This was probably due to the fact that sugar is a signal molecule and substrate for the synthesis of defensive molecules (Rosa et al., 2009).

Under this experimental condition, the two concentrations of $\mathrm{TiO}_{2} \mathrm{NPs}$ in the medium caused increased accumulations of TSS and all flavonoid subgroups in PAP1 transgenics and WT tissues. This would seem to correspond with the results of $\mathrm{TiO}_{2}$ NPs effects on the expression of flavonoid genes (Jeong et al., 2010). The high level of sugar can be converted into reducing power that is used for producing antioxidants that are used by the cells to lower the levels of ROS generated from $\mathrm{TiO}_{2} \mathrm{NPs}$ (Petrov et al., 2015). Previous research has dealt with the effects of sugar in inducing the expression of flavonoid biosynthetic genes (Xiao et al., 2000). Soluble sugars act as internal signals, which coordinate functions in the regulation of metabolic processes in plants (Rolland et al., 2002). MYB75/PAP1 regulatory protein is necessary for the function of the sugar regulating gene involved in flavonoid biosynthesis (Teng et al., 2005). Therefore, the overexpressing PAP1 protein in transgenic plants could enhance the response of sugar synthesis and; thus, cause an increase in the accumulations of flavonoids.

In the case of the medium containing $40 \mathrm{mg} \mathrm{L}^{-1} \mathrm{TiO}_{2} \mathrm{NPs}$, chlorophyll $a$ in the transgenics was at a similar level to the same transgenics grown under normal medium conditions, whereas chlorophyll $b$ and carotenoid levels in most transgenics were slightly higher than those in plants under normal condition. This result showed that $40 \mathrm{mg} \mathrm{L}^{-1} \mathrm{TiO}_{2}$ medium may be less or non-toxic to transgenic plants containing PAP1, compared to WT plants. This result indicated the better adaptations of transgenic plants under moderate to high concentration of $\mathrm{TiO}_{2}$, although the highest level of flavonoid subgroups was found in transgenic and WT plants grown under $40 \mathrm{mg} \mathrm{L}^{-1} \mathrm{TiO}_{2} \mathrm{NPs}$. Transgenic overexpressing $P A P 1$ gene plants contained higher flavone and flavonol levels than WT plants under $\mathrm{TiO}_{2} \mathrm{NPs}$ and non $\mathrm{TiO}_{2} \mathrm{NPs}$ conditions, while the level of anthocyanin subgroups was similar among the plants in the same conditions. The physiology of PAP1 transgenic plants was compared with those of normal WT plants, and the flavone and flavonol subgroups could wellmitigate the deleterious effects of $\mathrm{TiO}_{2} \mathrm{NPs}$. Moreover, these flavonoids are not only reducing the levels of radicals inside the cell but are also directly reducing the toxicity of metal ions (Chobot et al., 2013). Our result is similar to that of other researchers who reported that plants strongly produce flavonoids in their tissues to protect the photosynthetic apparatus against oxidative stress (Zheng et al., 2005; Su et al., 2009).

\section{Materials and Methods}

\section{Plant and treatments}

WT and transgenic tobacco overexpressing PAP1, T1-T5, as described by Sompornpailin and Kanthang (2015) were used in the experiment. Tobacco shoots were placed in MS medium containing a formula designed by Murashige and Skoog (1962) and MS medium with 20 and $40 \mathrm{mg} \mathrm{L}^{-1}$ of manufactured $\mathrm{TiO}_{2}$ NPs (24.0 $\pm 1.9 \mathrm{~nm}$; Evonik Industries). All samples were maintained under tissue culture conditions at $25 \pm 2{ }^{\circ} \mathrm{C}$ (18 hours in light and 6 hours in darkness) for 4 weeks before further analysis was undertaken.

\section{Effects of $\mathrm{TiO}_{2} \mathrm{NPs}$ on photosynthetic pigment contents}

The four-week old plants were cultured under 0,20 , and $40 \mathrm{mg}$ $\mathrm{L}^{-1}$ of $\mathrm{TiO}_{2} \mathrm{NPs}$ medium conditions that were used for analyzing the photosynthetic pigment contents in leaf tissue. Fifty milligrams of ground leaf powder were extracted with $1.5 \mathrm{ml}$ acetone and incubated at $4^{\circ} \mathrm{C}$ for 48 hours. The contents of chlorophyll a, chlorophyll b and carotenoid were estimated as described by Reiss (1994).

\section{Effects of $\mathrm{TiO}_{2} \mathrm{NPs}$ on cell membrane integrity}

Cell membrane integrity in plant tissue was estimated by two methods. The first method involved the detection of the level of malondialdehyde (MDA), a byproduct of lipid peroxidation in plant tissue. Plant tissue was ground into a powder and extracted with $0.1 \%$ trichloroacetic acid at room temperature for 1 hour and the residues were removed by centrifugation. An aliquot of each sample was tested following the thiobarbituric acid reactive substances assay (TBARS), following the method of Hodges et al. (1999).

Second, the percentage of cell membrane injury was calculated by comparing the electrical conductivity (EC) of the treated sample with total EC content after boiling the sample. This protocol was a modified version of the method of Bajji et al. (2002). Leaf samples were cut into small pieces and dipped into deionized water at $30 \circ \mathrm{C}$ for 30 minutes. The initial electrical conductivity (ECi) of the plant dipped into water was measured by a conductivity meter. The final electrical conductivity (ECf) was measured after six hours of plant immersion. The water containing pieces of leaves was boiled at 100 ㄷ for 1 minute. The sample was cooled down and the total 
electrical conductivity (ECt) was then measured. The EC values of each sample were collected, and the electrolyte leakage calculated and presented as the percentage of cell membrane injury using the following equation:

$$
\text { Cell membrane injury }(\%)=\frac{\mathrm{ECf}-\mathrm{ECi}}{\mathrm{ECt}-\mathrm{ECi}} \times 100
$$

\section{Effects of $\mathrm{TiO}_{2} \mathrm{NPs}$ on metabolic responses}

In this experiment, the levels of total soluble sugar, which is a basic energy resource, and flavonoids, which are antioxidant substances, were analyzed in leaf samples. The extraction method of TSS followed Shou et al. (2004) method. Typically, a $500 \mathrm{mg}$ leaf sample was ground in liquid nitrogen and extracted with $80 \%$ ethanol. The sample was agitated at 250 rpm at room temperature for 1 hour and kept at $4{ }^{\circ} \mathrm{C}$ overnight. The supernatant was separated from insoluble residuals by centrifugation. Equal volumes of water and chloroform were added to the separated supernatant and mixed well. This mixture was then centrifuged. The supernatant was transferred to a new tube and diluted to $10 \mathrm{X}$ with DI water. A $100 \mu \mathrm{l}$ sample of the solution was analyzed for total soluble sugar using the Phenol-Sulfuric method as described by DuBois et al. (1956). TSS of the sample was calculated from a standard calibration curve of sucrose.

Flavonoid extraction and analysis were performed as described by Harborne (1998). A $500 \mathrm{mg}$ leaf sample was used for flavonoid analysis by extraction with $2 \mathrm{ml}$ extraction buffer ( $\mathrm{MeOH}: \mathrm{H}_{2} \mathrm{O}, 2: 3$ ) with $1 \% \mathrm{HCl}$. The sample was agitated at room temperature at $250 \mathrm{rpm}$ for 2 hours, and then chlorophylls were precipitated with chloroform. The flavonoid content of the solution was measured via spectrophotometer with the specific absorbance of flavonoid subgroups being checked absorbance values of the sample was calculated per gram fresh weight $\left(\mathrm{A} \mathrm{g}^{-1} \mathrm{FW}\right)$. The mean $\pm \mathrm{SD}$ of $\mathrm{A} \mathrm{g}^{-1} \mathrm{FW}$ in each treatment was presented.

\section{Statistical analysis}

The treatments were manipulated in completely randomized design (CRD) with 3 replicates. Statistical analysis was performed using one-way analysis of variance (ANOVA) and Duncan's multiple range test (DMRT). The data were presented as means \pm SD. Significance at a $P$ value $\leq 0.05$ differences among means were determined by LSD test.

\section{Conclusion}

The toxicity of $\mathrm{TiO}_{2}$ NPs depends on their concentration at specific conditions. In this experiment, $20 \mathrm{mg} \mathrm{L}^{-1} \mathrm{TiO}_{2} \mathrm{NPs}$ in culture medium had beneficial effects on plant physiological parameters (photosynthetic pigments, cell membrane injury) because elemental titanium has synergistic functions with elemental iron. A culture medium containing $40 \mathrm{mg} \mathrm{L}^{-1} \mathrm{TiO}_{2}$ NPs may enhance oxidative stress and cell membrane injury of WT plants. The flavone and flavonol contents of the plant tissues of PAP1 transgenics were analyzed. We concluded that a relationship between enhanced plant protection and concentrations of $\mathrm{TiO}_{2} \mathrm{NPs}$ in the medium is present.
Transgenic plants that contained high flavone and flavonol levels have a greater potential to relieve the harmful effects of oxidative $\mathrm{TiO}_{2} \mathrm{NPs}$ than do WT plants.

\section{References}

Bajji M, Kinet JM, Lutts S (2002) The use of the electrolyte leakage method for assessing cell membrane stability as a water stress tolerance test in durum wheat. Plant Growth Regul. 36:61-70.

Chayaprasert W, Sompornpailin K (2017) Suitable concentration of $\mathrm{ZnO}$ nanoparticles enhanced biomaterial synthesis and plant cell protection. Appl Mech Mater. 866:21-24.

Chobot V, Kubicova L, Bachmann G, Hadacek F (2013) Versatile redox chemistry complicates antioxidant capacity assessment: flavonoids as milieu-dependent anti- and prooxidants. Int J Mol Sci. 14:11830-11841.

Da Costa MVJ, Sharma PK (2016) Effect of copper oxide nanoparticles on growth, morphology, photosynthesis, and antioxidant response in Oryza sativa. Photosynthetica. 54:110-119.

DuBois M, Gilles KA, Hamilton JK, Rebers PA, Smith F (1956) Colorimetric method for determination of sugars and related substances. Anal Chem. 28: 350-356.

Dujardin E, Laszlo P, Sacks D (1975) The chlorophylls. An experiment in bio-inorganic chemistry. J Chem Educ. 52:742.

Gao F, Liu C, Qu C, Zheng L, Yang F, Su M, Hong F (2008) Was improvement of spinach growth by nano- $\mathrm{TiO}_{2}$ treatment related to the changes of Rubisco activase. Biometals. 21:211-217.

Gázquez MJ, Bolívar JP, Garcia-Tenorio R, Vaca F (2014) A review of the production cycle of titanium dioxide pigment. MSA Sci Res. 5:441-458.

Harborne AJ (1998) A guide to modern techniques of plant analysis. Phytochemical methods, $3^{\text {rd }}$ edn. Springer Netherlands, Netherlands.

Hodges DM, DeLong JM, Forney CF, Prange RK (1999) Improving the thiobarbituric acid-reactive-substances assay for estimating lipid peroxidation in plant tissues containing anthocyanin and other interfering compounds. Planta. 207:604-611.

Hong F, Yang F, Liu C, Gao Q, Wan Z, Gu F, Wu C, Ma Z, Zhou J, Yang $P$ (2005a) Influences of nano- $\mathrm{TiO}_{2}$ on the chloroplast aging of spinach under light. Biol Trace Elem Res. 104:249260.

Hong F, Zhou J, Liu C, Yang F, Wu C, Zheng L, Yang P (2005b) Effect of nano- $\mathrm{TiO}_{2}$ on photochemical reaction of chloroplasts of spinach. Biol Trace Elem Res. 105:269-279.

Jeong SW, Das PK, Jeoung SC, Song JY, Lee HK, Kim YK, Kim WJ, Park YI, Yoo SD, Choi SB, Choi G, Park YI (2010) Ethylene suppression of sugar-induced anthocyanin pigmentation in Arabidopsis. Plant Physiol. 154:1514-1531.

Kaveh R, Li YS, Ranjbar S, Tehrani R, Brueck CL, Van Aken B (2013) Changes in Arabidopsis thaliana gene expression in response to silver nanoparticles and silver ions. Environ Sci Technol. 47:10637-10644. 
Lyu S, Wei X, Chen J, Wang C, Wang X, Pan D (2017) Titanium as a beneficial element for crop production. Front Plant Sci. 8:597.

Marslin G, Sheeba CJ, Franklin G (2017) Nanoparticles alter secondary metabolism in plants via ROS burst. Front Plant Sci. 8:832.

Miralles P, Church TL, Harris AT (2012) Toxicity, uptake, and translocation of engineered nanomaterials in vascular plants. Environ Sci Technol. 46:9224-9239.

Mohammadi R, Maali-Amir R, Mantri NL (2014) Effect of $\mathrm{TiO}_{2}$ nanoparticles on oxidative damage and antioxidant defense systems in chickpea seedlings during cold stress. Russ J Plant Physiol. 61:768-775.

Murashige T, Skoog F (1962) A revised medium for rapid growth and bioassays with tobacco tissue cultures. Physiol Plant. 15:473-497.

Øyvind MA, Kenneth RM (2006) Flavonoids: chemistry, biochemistry and applications. CRC Press Taylor \& Francis Group, Florida.

Petrov V, Hille J, Mueller-Roeber B, Gechev TS (2015) ROSmediated abiotic stress-induced programmed cell death in plants. Front Plant Sci. 6:69.

Pilon-Smits EA, Quinn CF, Tapken W, Malagoli M, Schiavon M (2009) Physiological functions of beneficial elements. Curr Opin Plant Biol. 12:267-274.

Raliya R, Biswas P, Tarafdar JC (2014) $\mathrm{TiO}_{2}$ nanoparticle biosynthesis and its physiological effect on mung bean (Vigna radiata L.). Biotechnol Rep. 5:22-26.

Reiss C (1994) Experiments in plant physiology. Prentice Hall, New Jersey.

Rolland F, Baena-Gonzalez E, Sheen J (2006) Sugar sensing and signaling in plants: conserved and novel mechanisms. Annu Rev Plant Biol. 57:675-709.

Rolland F, Moore B, Sheen J (2002) Sugar sensing and signaling in plants. Plant Cell. 14:185-205.

Rosa M, Prado C, Podazza G, Interdonato R, Gonzalez JA, Hilal M, Prado FE (2009) Soluble sugars-metabolism, sensing and abiotic stress: a complex network in the life of plants. Plant Signal Behav. 4:388-393.

Ruffini CM, Giorgetti L, Geri C, Cremonini R (2010) The effects of nano- $\mathrm{TiO}_{2}$ on seed germination, development and mitosis of root tip cells of Vicia narbonensis L. and Zea mays L. J Nanopart Res. 13:2443-2449.
Schneider J, Matsuoka M, Takeuchi M, Zhang J, Horiuchi Y, Anpo M, Bahnemann DW (2014) Understanding $\mathrm{TiO}_{2}$ photocatalysis: mechanisms and materials. Chem Rev. 114: 9919-9986.

Shou H, Bordallo P, Fan JB, Yeakley JM, Bibikova M, Sheen J, Wang $K$ (2004) Expression of an active tobacco mitogenactivated protein kinase enhances freezing tolerance in transgenic maize. Proc Natl Acad Sci. 101:3298-3303.

Solfanelli C, Poggi A, Loreti E, Alpi A, Perata P (2006) Sucrosespecific induction of the anthocyanin biosynthetic pathway in Arabidopsis. Plant Physiol. 140:637-646.

Sompornpailin K, Kanthang S (2015) Tobacco expressing PAP1 increases the responses to PAR and UV-A by enhancing soluble sugars and flavonoids and elevating plant protections. Pak J Bot. 47:595-602.

Song G, Gao Y, Wu H, Hou W, Zhang C, Ma H (2012) Physiological effect of anatase $\mathrm{TiO}_{2}$ nanoparticles on Lemna minor. Environ Toxicol Chem. 31:2147-2152.

Stander L, Theodore L (2011) Environmental implications of nanotechnology-an update. Int J Environ Res Public Health. 8:470-479.

Su M, Liu H, Liu C, Qu C, Zheng L, Hong F (2009) Promotion of nano-anatase $\mathrm{TiO}_{2}$ on the spectral responses and photochemical activities of D1/D2/Cyt b559 complex of spinach. Spectrochim Acta A Mol Biomol Spectrosc. 72:11121116.

Teng S, Keurentjes J, Bentsink L, Koornneef M, Smeekens S (2005) Sucrose-specific induction of anthocyanin biosynthesis in Arabidopsis requires the MYB75/PAP1 Gene. Plant Physiol. 139:1840-1852.

Wang X, Yang X, Chen S, Li Q, Wang W, Hou C, Gao X, Wang L, Wang S (2015) Zinc oxide nanoparticles affect biomass accumulation and photosynthesis in Arabidopsis. Front Plant Sci. 6:1243.

Xiao W, Sheen J, Jang JC (2000) The role of hexokinase in plant sugar signal transduction and growth and development. Plant Mol Biol. 44:451-461.

Yang Z, Chen J, Dou R, Gao X, Mao C, Wang L (2015) Assessment of the phytotoxicity of metal oxide nanoparticles on two crop plants, Maize (Zea mays L.) and Rice (Oryza sativa L.). Int J Environ Res Public Health. 12:15100-15109.

Ze YG, Liu C, Wang L, Hong MM, Hong FS (2011) The regulation of $\mathrm{TiO}_{2}$ nanoparticles on the expression of light-harvesting complex II and photosynthesis of chloroplasts of Arabidopsis thaliana. Biol Trace Elem Res. 143: 1131-1141.

Zheng L, Hong F, Lu S, Liu C (2005) Effect of nano- $\mathrm{TiO}_{2}$ on strength of naturally aged seeds and growth of spinach. Biol Trace Elem Res. 104:83-92. 